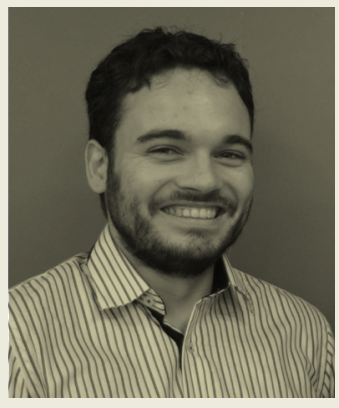

\title{
OS NOVOS ARRANJOS POLÍTICOS E OS DESAFIOS DA DEMOCRACIA
}

Algo não vai bem nos sistemas representativos pelo mundo. A (re)emergência do populismo tanto no norte quanto no sul, juntamente com traços autoritários que muitos julgavam superados, acendem alertas nas democracias e deveriam fazer o mesmo com os mercados. O sucesso eleitoral de estratégias populistas pode ser visto como mais um sintoma da crise nas democracias liberais capitalistas.

Esses movimentos devem ser compreendidos tanto em termos de aspectos econômicos como pela sua dimensão cultural. De um lado, é necessário reconhecer que, embora a globalização e a integração de mercados tenham trazido ganhos a vários grupos, há também aqueles que perderam status econômico ou social no mesmo período. De outro, tem-se uma reorganização cultural na arena pública, transformando o que pode ser dito ou confrontado e rompendo com consensos mais ou menos estabelecidos há décadas.

No Brasil, os avanços trazidos pela Constituição democrática de 1988 são inegáveis. Naquele momento, a sociedade pactuou direitos essenciais para o exercício da cidadania. Por exemplo, o Sistema Único de Saúde (SUS) e o sistema de ensino só passaram a ser vistos como algo a ser universalizável após 1988. Ainda que com deficiências, os avanços em ambos os campos são evidentes, no entanto ouve-se com frequência que "antigamente" educação ou saúde eram melhores. Argumentos como esse tendem a ignorar a cobertura de tais serviços e até o impacto da urbanização e do adensamento demográfico na demanda por mais direitos.

A inclusão de mais pessoas como cidadãos induziu a sociedade civil e o sistema político a se reorganizarem para acomodar grupos antes excluídos.
Os novos participantes transformaram os equilíbrios com os quais parte da população estava acostumada. Ao mesmo tempo, a economia brasileira não conseguiu avançar o suficiente para evitar novos conflitos.

Os avanços tímidos no combate à desigualdade, somados a uma duradoura crise político-econômica, colocaram novos desafios para a sociedade brasileira, que não havia superado completamente os problemas do passado. A fatia da economia que fica com as classes médias diminuiu ou cresceu menos do que o esperado no século XXI. A competição por espaço nesse mesmo grupo aumentou e, como diz o ditado, em casa que falta pão, todo mundo briga e ninguém tem razão.

Aproximar o discurso político das pessoas e de suas demandas, como supostamente fazem os populistas, surte efeito nesse momento, mas há que se monitorar a saúde da democracia. Propostas como a de liberar o mercado a qualquer custo podem parecer um ganho de liberdade geral, contudo deve-se lembrar que, sem democracia plena, tanto a sociedade civil quanto a liberdade de mercado podem ser vitimadas no médio prazo. $\mathrm{O}$ autoritarismo e o Estado ensimesmado abrem espaço para oligarquias e favoritismos substituírem a competição de ideias ou de bens e serviços.

Veremos emergir novos conflitos sobre o papel do Estado. Deve este ser de bem-estar, atuar como regulador ou apenas como vigia noturno? A resposta a essa questão incorrerá em efeitos concretos. Por exemplo, qual é o papel do SUS, das organizações sociais, dos vouchers e dos prestadores privados na saúde nesse contexto? Os novos tempos também implicarão novas articulações em torno do papel do mercado e da sociedade civil na vida do país. 